\title{
The Wine Vault And Bistro: A Case Study
}

Melissa St. James, Ph.D., California State University - Dominguez Hills, USA

\begin{abstract}
This case study details the creation and evolution of an entrepreneurial effort started by a 7 year old girl and continued by her entire family. What began as a young girl's way to earn money without selling her toys has evolved into a successful restaurant and wine bar called The Wine Vault \& Bistro, tucked away in the South Mission Hills neighborhood of San Diego, CA. This case has been prepared as the basis for classroom discussion and is not intended to illustrate either effective or ineffective business practices. Sample discussion questions are included at the conclusion of the case itself.
\end{abstract}

Keywords: Entrepreneurship, women in business.

\section{A SMALL BEGINNING}

n the early 1990s, in a down economy, Erica Gluck, at the age of 7, decided she needed to earn her own money. Her favorite food at the time was pasta and so she decided, logically, that everyone would enjoy this delicious, nutritious food. With the help of her parents, Erica purchased homemade pasta from a nearby pasta shop and proceeded to the local farmers market. She sold each and every bag of pasta that weekend and a business was born.

Erica's pasta business evolved to include pesto, olive oils and breads and the family began a fulltime involvement. There was even Pasta Press, publishing pasta cookbooks. Eventually, Erica's younger sister Katie began a side business called Katie's Koop, selling fresh eggs alongside the pasta and accessories of her sister. Erica's parents, Mary and Chris, devoted all their time to the business and the family truly learned what togetherness meant... while working hard and supporting the entire family doing something they loved.

What began as a weekend endeavor with an investment of under \$200 (including inventory and a tablecloth!) became the support for a family of four. The children learned a strong work ethic and the family learned to follow their dreams. In 2003, after nearly 10 years in business, the Glucks sold the location and relationships for a sum in the mid-five figures and looked forward to pursuing new dreams.

\section{GROWTH AND EVOLUTION}

During the final 2 years of the pasta and egg business (2001-2003), the family patriarch, Chris Gluck, began following one of his interests, a love of wine. The farmers' market business allowed Chris to indulge this hobby without fearing for the economic health of his family. Through a relationship with a San Diego wine store, The Wine Bank, Chris parlayed an email newsletter into the next family business.

Approaching the Wine Bank with an idea, Chris started small and grew. Amassing a list some 1000 strong from signup sheets at the local farmers markets where the family was conducting business, Chris earned $\$ 30$ for putting out a weekly email newsletter for the Wine Bank, featuring four wines each week. Chris tasted each wine himself, building his knowledge base by 16 wines a month. This free education was a vital contribution to Chris in building his knowledge of a vast variety of wines, and at no cost to himself.

After only 4 months, Chris held his first event at the Wine Bank; he called it "Big Reds and BBQ." Chris chose the wines and a local San Diego BBQ joint catered the food. With a prix fixe of about $\$ 40$ for dinner and wine, the event drew some 30 people and a new entrepreneurial endeavor was afoot. 
Within three years the events were drawing 250 people over 5 nights... and exhausting the owner of the Wine Bank! Chris secured a new venue, The Gathering, in Mission Hills, a neighborhood in San Diego not far from downtown. Buying wine under The Gathering's license, Chris ran his new tastings in a slightly different format, with a profit now being made on the wine sales. Through word of mouth, and no advertising, the events continued to grow in size and eventually the Glucks knew it was time for a home of their own.

\section{THE WINE VAULT \& BISTRO}

While strolling one morning in their own neighborhood, the Glucks noticed a location with potential. Upon approaching the owner, problems became apparent but the Glucks held out, eventually buying the lease from the owner for a low six figure sum, with a couple of key caveats. The lease would remain at the same rate and the length of the lease would not change (the terms included a 5 year option, another 5 year option and then a 10 year option). The property was leased as is and Chris and Mary would also have to be able to secure a beer and wine license for the location. In July of 2004 the deal was closed and the real work began. It would be over a year and a half before opening day of The Wine Vault and Bistro.

During renovations obstacles were encountered that threatened to halt the endeavor, including the discovery that a great deal of foundation work was needed in order to proceed. Mary and Chris had no idea that a very unusual situation would work in their favor - a rain delay...in San Diego, CA. During the lease negotiations, a deal had been struck that allowed for no rent (and an extension on the lease) in the event of a rain delay during the foundation repairs and renovations. The upside? Mary and Chris were able to work on the interior of the location during the rain delay....all the while enjoying free rent.

Mary Gluck, trained as an Interior Designer, has created an unusually stark but yet inviting space for the Wine Vault \& Bistro (See Exhibit 1 for photos). The wine serves as the art, lining the walls in nooks and on shelves. The walls are white, the tables clean, natural wood, the accessories stainless steel. A typical wine bar is dark and cellar-like, the Wine Vault \& Bistro stands out because it is different; it is clean, uncluttered and inviting. The dining room features a warm fireplace and the patio has a large fire pit in the center.

On October 26, 2005 the Wine Vault officially opened its doors. Within a year it was being called "the most intriguing new restaurant of the year" by San Diego Home/Garden Lifestyles magazine (See Exhibit 1 for a list of media mentions and selected articles). The Wine Vault not only captured the attention of San Diego diners but it has been profitable from the start, relying solely on word of mouth rather than advertising.

\section{THE WINE VAULT \& BISTRO'S PHILOSOPHY}

Mary and Chris Gluck, inspired by their children's entrepreneurial success, had launched their business and were now following their own dreams. The Wine Vault is a full-fledged restaurant and wine bar, with a retail wine selection. The Glucks wanted a restaurant they themselves would want to frequent and their personal philosophies are evident in many aspects of the business. What they ended up creating has been called "personal and eccentric" by San Diego Home/Garden Lifestyles Magazine (see Exhibit 1).

Relationships are important to the Glucks and their business success depends on creating and fostering relationships with several parties; wine makers and representatives, Wine Vault employees and the customers. Each party has its own needs and desires, along with expectations.

\section{Winemakers and Winery Representatives}

The wines Chris and Mary feature at the Wine Vault come from many regions and wineries and often vary greatly from event to event. Wines are sold in California by representatives or distributors and Chris has established relationships with not only these middlemen but with the winery owners themselves. Vintners and winery owners often co-host the events at the Wine Vault, offering winery history and anecdotes from their own experiences and lending a human face to the brands. This contact allows the wine makers to know how their wines are being received and how the Wine Vault is representing them. It also allows the wine makers direct contact with customers 
who might not otherwise visit a winery on their own. The reputation Chris and Mary have among the wine makers leads to a remarkable ability to offer unusual wines and exclusives. The wine makers generally speak at the dinners and they invariably relate how the appeal and charm of the owners drew them in and keeps them coming back, some from as far as Australia, on a regular basis to share new vintages and new stories.

\section{Wine Vault Employees}

Mary Gluck has a focused philosophy when it comes to Wine Vault employees...her mission is to assist them in following their dreams. She tends to hire college educated workers who have dreams of their own to nurture and she allows them the flexibility to pursue those dreams while earning a near fulltime salary working part-time hours. Many employees stay for several years while attending university, while others stay as long as necessary to make the next move toward their personal goals. Employees are knowledgeable and friendly yet professional. Katie, the youngest daughter, worked many nights serving customers for a period of time before leaving for a local university but still returns to take the reins when her parents take buying or educational winery tours/trips and during her summer breaks. It's Katie who likes to say that the "employees are family at the Wine Vault \& Bistro."

\section{The Customers}

Finally, the customers are key to the Wine Vault's success. One of the most interesting facts about the Wine Vault is that it employs no advertising. This, coupled with the nearly hidden location, make it apparent that customers almost have to know someone who has visited the Wine Vault before they can discover it themselves. This makes for a familial feel when visiting the Wine Vault. It is like a large group of old friends simply dining and enjoying the evening.

Although Mary describes the typical Wine Vault customer as between 40 and 50 years old, she offers a Wednesday night Single's Night, serving less expensive wines, that attracts a decidedly younger crowd. These nights were originally instituted to fill a normally slow night at the venue and the side effect is that these folks now spread the word as well. On any given night the crowd ranges in age from 21 (of course!) to 60+, mingling and enjoying themselves in spite of, or more likely because of, the diversity. The Wine Vault \& Bistro "regularly serves everyone from multimillionaires to school teachers." According to 944 Magazine (November 2007).

Customers attending a Wine Vault event find themselves greeted personally by either Mary or Chris (often with a hug) and seated in a beautifully simple dining room or outside in the covered patio near a large fire pit. The tables seat from 2 to 12 diners and one is sometimes seated with strangers... who might become friends by the end of the night. As expected, many customers become regulars and attend several events monthly. Others choose special events based on either the winery being featured or the delectable menu created by Chris. Mary comments that she likes to seat customers with those who might be liked-minded. For instance, if she knows one small group is from the Pacific Beach neighborhood in San Diego, she might seat them with another group from that area. If she knows your profession she might introduce you to and seat you with someone in the same or a compatible field. The hands on approach of the owners makes for a friendly atmosphere and makes customers feel at home.

Near the end of each night Mary makes the rounds of the restaurant, clipboard in hand, to allow customers to sign up for the emails Chris so lovingly puts together on a regular basis. The email for any given event includes detailed descriptions of the wines and the menu for the event, parking advice, contact information and a healthy dose of Chris's personality. The web site for the Wine Vault \& Bistro is similar in appearance to the location itself; clean, clear and simple yet friendly. The calendar allows customers to click on any date and see the menu and event offered for that evening. Another personal touch is that Chris or Mary try to return all emails and phone calls personally and promptly, confirming reservations, or clarifying information.

\section{THE STRUCTURE OF THE WINE VAULT \& BISTRO'S OFFERINGS}

The Wine Vault \& Bistro is all about pairing great wines with great food in a comfortable atmosphere. The menu can run from local smoked meats or braised beef cheeks to exotic mushrooms or edamame hummus. The daily 
or weekly menus vary depending on the winery and the wines featured but the wine pairings are always truly remarkable.

The seasonal Bistro menu is available most every night but menu items may change often and the wine events vary from day to day, albeit within a model. For example:

- $\quad$ Saturday nights are devoted to a Chef's 5-course Tasting Menu, paired with wines (see Exhibit 2)

- $\quad$ Friday nights are devoted to Prix Fixe Menu + Wine Flights (see Exhibit 3)

- $\quad$ Tuesdays, Wednesdays and Thursdays are often the Winemaker dinners with visiting winery owners and representatives (see Exhibit 4), or

- Informal, self-serve wine flights with the Bistro Menu available (see Exhibit 5).

This last example, the self serve option, is unique in that the customer takes the wine flight ticket directly to the bar and the bartender checks off each wine as the customer "orders" it. This is a self paced adventure, rather than the more structured winemaker dinners where the customer is seated and the wines are served to them at the table. It also gives customers a chance to mingle at the bar and to meet other customers throughout the night.

One of the best features of the Wine Vault \& Bistro offerings is that Chris and Mary have perfected the model and present a reasonable price structure. The Bistro Menu, available most nights except during the winemaker events, offers starters such as pomme frites and bacon-wrapped stuffed dates from around $\$ 6.00$, and entrees reasonably priced starting at around $\$ 11.00$. A prix fixe dinner menu is usually $\$ 20$ for three courses and winemaker dinners start at around $\$ 49.50$. Wine flights, offered with the prix fixe, range from $\$ 10-20.00$ for 3-5 wines.

Reservations are required for the wine maker events, and are encouraged for other nights simply due to the restaurant's popularity. Wine maker dinners require a credit card to hold the reservations and the card is charged prior to the event, although there is a 72 hour cancellation policy. Sales tax and an $18 \%$ gratuity are added to all prepaid checks. Bottled wines can be purchased off the shelf after any event, and these are often limited releases and are offered at less than the customer could find at the winery itself or elsewhere.

\section{SUMMARY}

Mary Gluck describes the success of The Wine Vault as hinging on four aspects: ambiance, food, wine and staff. Each of these is unique in its contribution yet each draws from the others to create a truly successful business. The entrepreneurial adventure of their two young girls has grown, somewhat organically, into a thriving business for Mary and Chris Gluck. The Wine Vault \& Bistro still conducts no advertising.

\section{CASE QUESTIONS FOR DISCUSSION}

1. After reading the case and examining Exhibit 1: Media Mentions, describe the positioning of the Wine Vault \& Bistro. How might a change to a more aggressive marketing/advertising strategy affect the image of the Wine Vault \& Bistro?

2. Considering the philosophy of the owners, the nature of the clientele and the positioning of the business, should the Glucks stick to their current business strategy or should they change it?

3. Should the Glucks consider expanding their operation through either franchising or simply opening another location themselves? How would this affect their overall operation and image?

\section{AUTHOR INFORMATION}

Melissa St. James is an assistant professor of marketing in the Management and Marketing Department at California State University Dominguez Hills. She earned her PhD from The George Washington University, her MBA from Meredith College, and her BA from The University of Cincinnati. Her varied research interests include celebrity endorsements, wine consumption, online teaching and the history of advertising. She has provided expert witness testimony at trial, interviews in various local and national news media and her work has been published in a number of academic and professional journals. 


\section{EXHIBIT 1: MEDIA ATTENTION}

“No Kidding," Kiplinger's, Sept. 2001, pages 110-112.

"For the Love of Pasta," Kids' Wall Street News, Page 15.

"Coming Home," San Diego Home/Garden Lifestyles, page 160.

"Two by Two," San Diego Weekly Reader, Aug. 31, 2006.

"Success is in the Tinkering," San Diego Weekly Reader, Sept. 7, 2006.

"Not Just for Oenophiles," San Diego City Beat, Oct. 4, 2006.

"Dining: Flight Arrival," Where San Diego Magazine, Page 9, Fall 2006.

"Wine Vault \& Bistro," 944 San Diego, Page 53, Nov 2007.

Where San Diego Magazine, Page 19, Winter 2008.

"Wine Vault Event was Pair for the Course," San Diego Downtown News.

"On the Plate: Good eats," Performances Magazine (SD Symphony), Page 54-55, Jan. 2008.

"Stone Brewing and Wine vault Bistro Make a Meal to Remember," San Diego Downtown News, Pages 10-11, April 2009. 


\section{EXHIBIT 1 (continued): MEDIA ATTENTION}

For the

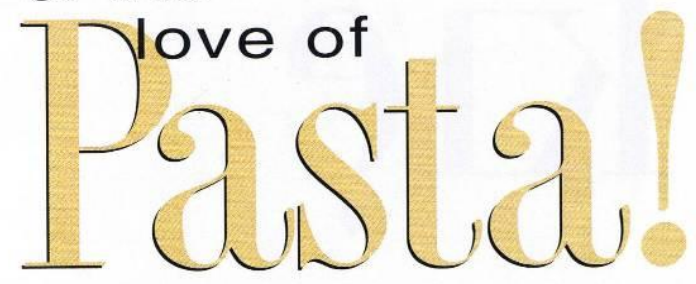

By Gayle Feallock

Ask Erica Gluck what one of her favorite foods is and she'll reply, "Mexican chili pasta."

Erica knows a lot about pasta. She likes it so much that three years ago, at the age of 7 , Erica persuaded her parents to let her set up a stand selling fresh pasta at her local farmers' market.

Erica's parents never dreamed her pasta stand would make a lot of money, but they let her take a chance selling Erica's Fresh Pasta.

"Even if it doesn't work you learn through the process," said Chris Gluck, Erica's father.

But it did work. Erica's pasta stand expanded to several other farmers' markets and became so popular that her parents began a magazine for pasta recipes called Pasta Press. "I'm really proud of my parents that they let me try," Erica says.

So why did Erica want to turn her love of pasta into a money-making venture? She said she wanted to start a business to make more money for college, to buy a car and "so I was prepared for my future."

Erica says she doesn't want to depend on her parents for everything and will feel good knowing she worked hard and saved for her purchases.

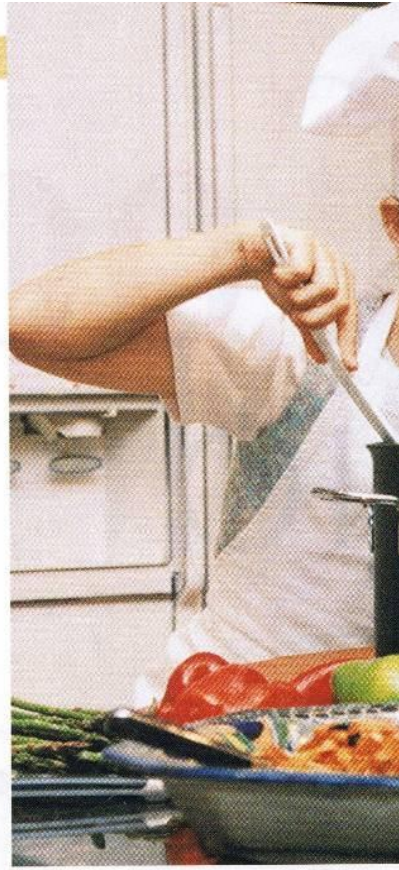

Aside from making money through her love of pasta, Erica has a message for kids. She wants them to learn to eat healthy.

"A lot (of kids) are growing up unhealthy and stay unhealthy and teach their kids" the same eating habits.

"I want everyone to

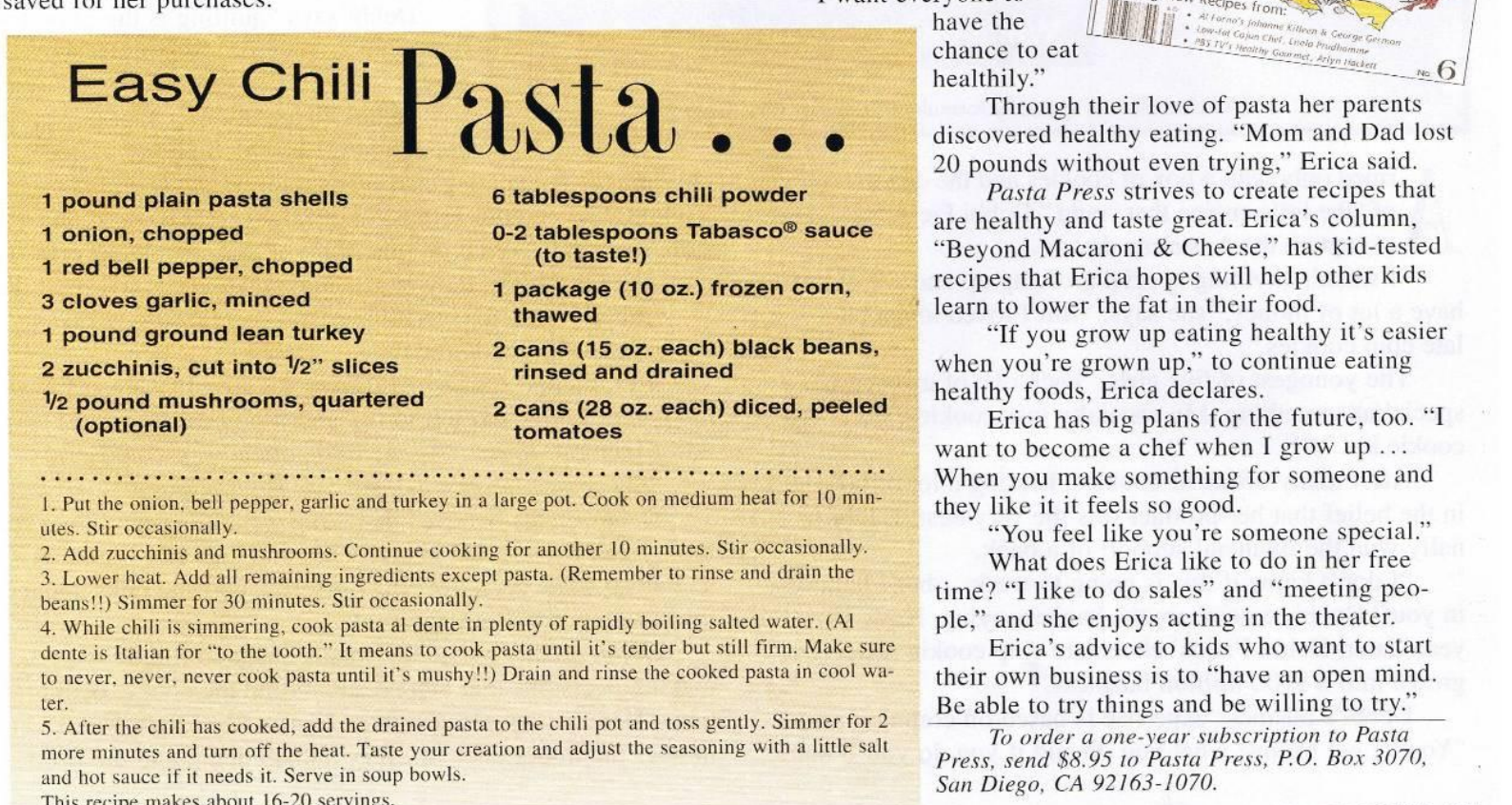

This recipe makes about 16-20 servings.

KIDS' WALL STREET NEWS 15 


\section{EXHIBIT 1 (continued): MEDIA ATTENTION}

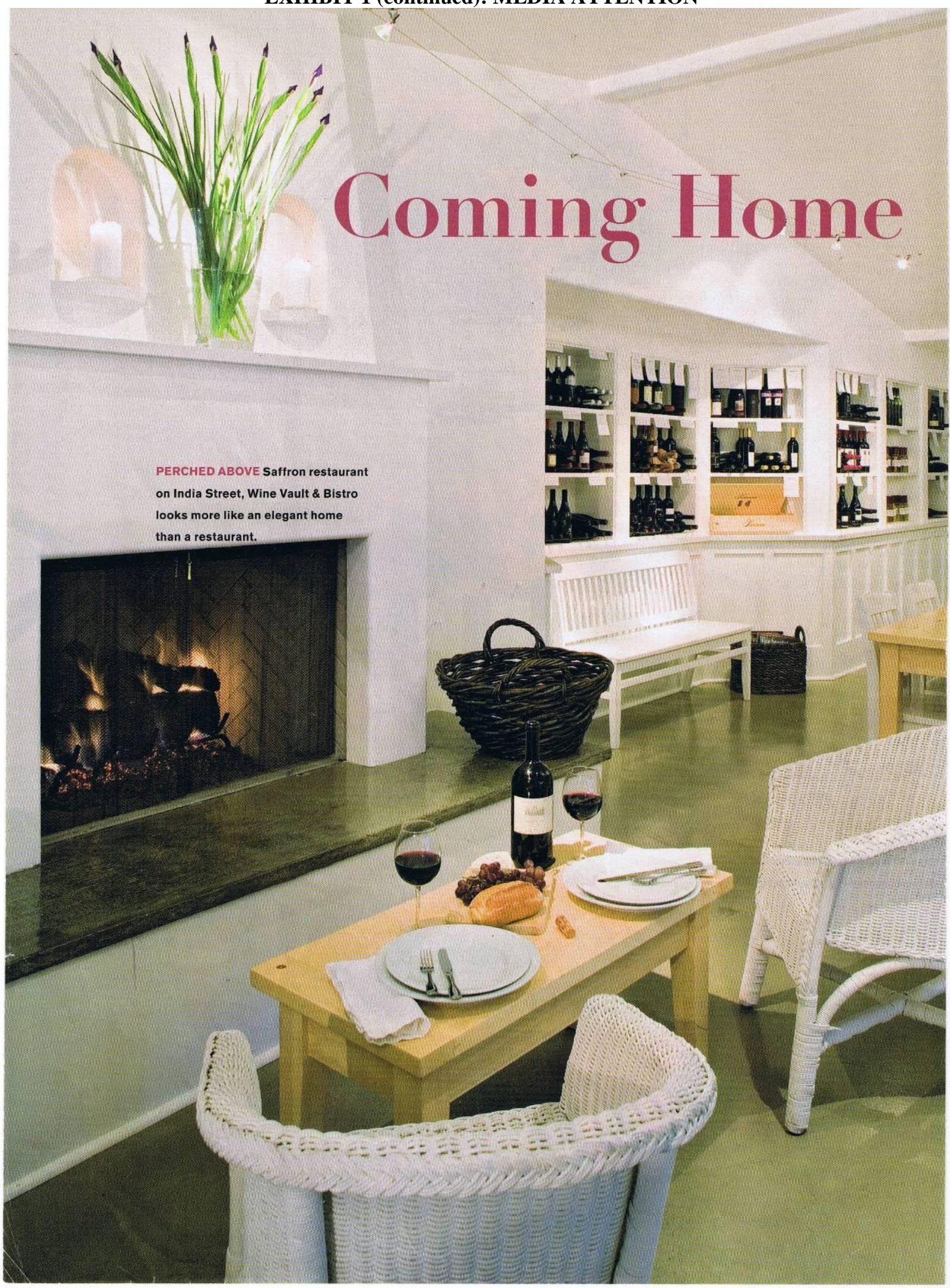




\section{EXHIBIT 1 (continued): MEDIA ATTENTION}

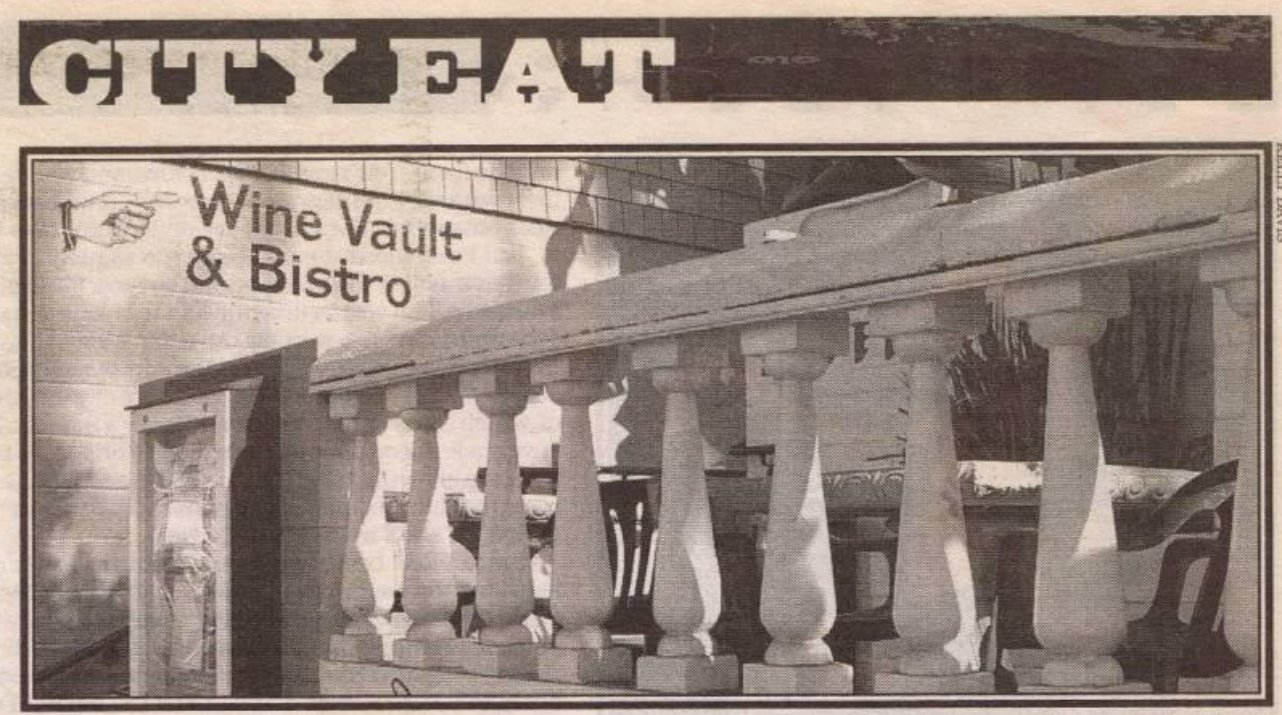

An old-timey hand points the way to Wine Vault's perch above India Street.

\section{Not just for oenophiles}

The Wine Vault \& Bistro

HAS LOTS TO OFFER

BY CANDICE WOO

It's $3: 30 \mathrm{p} . \mathrm{m}$. on Friday and I see those three words in the subject line of an e-mail from a friend: "Wine Vault Friday?" Maybe it's because my work week is almost finished, or perhaps that last Diet Coke I drank is kicking in, but the tension I've been carrying around all day in my shoulders eases and I find myself doing a little jig on my way to the office copier. Even getting stuck in rush-hour traffic doesn't seem so bad because I know where I'm headed.

If I were better at keeping secrets, I probably wouldn't be writing about this place; it's already tough enough to score a table on Friday nights. But, honestly, some things are too good not to share.

Chris and Mary Gluck, owners of the Wine Vault \& Bistro on India Street, have transformed the once drab and dark space above Saffron Chicken into a clean, airy modern dining room with a fireplace inside and fire pit on a outside candlelit patio.

So what makes it a weekly must-visit? The wine helps, of course: You can choose from the bottles on the shelves that line the room or ask your waiter to choose one for you-I usually just say how much I want to spend and ask what's good for that price. This past Friday, our adorable waiter, Josh, started us off with a bottle of his favorite wine, the Australian Kaesler Avignon, a lip-smacking fruit-and-spice bomb of a Rhone blend that paired perfectly with our juicy pork chops topped with apple chutney. And, if you happen to be hovering at the bar at the right time, Chris Gluck might let you sample one of his picks. If you're feeling indecisive, there are tasting flights and samplings of a couple different varietals to help narrow the field.

If you're in the mood for the harder stuff, the Wine Vault's single-malt scotch and small-batch bourbon collections can be pretty tempting. A good bet is Booker's Bourbon - the only uncut, unfiltered, straightfrom-the-barrel, connoisseur's sipping bourbon currently available. Booker's is named after Jim Beam's grandson, Booker Noe, a master distiller emeritus, who hand selects each barrel (how's that for trivia?).

The food keeps me coming back, too. Wine Vault's menu goes beyond the standard wine-bar cheese plates and features a selection of well-priced and uniformly tasty dishes, ranging from small bites to heartier meats and pastas that are great for sharing. My friends and I usually start with a crisp panini sandwich made with spicy andouille sausage paired with peppers, onions and mozzarella. It's also hard to resist the piping-hot pommes frites (aka French fries), the world's greatest bar food. Our appetites whetted by wine, we'll move on to tender chicken picatta or the previously mentioned pan-seared pork chops with a sweetly spiced apple chutney accompaniment. And no meal is complete without the Wine Vault's sublime raspberry-liqueur. infused chocolate mousse. Its arrival at the table always elicits audible moans of pleasure from guys and girls alike. Most plates are priced under $\$ 10$, making it easy and affordable to cobble together an ample spread.

What really makes the Wine Vault special, though - at least for me-are the people. The place is devoid of wine snobs, and the regular clientele and waitstaff are all kindred food-and-drink lovers, ready to share a wine tip or an "Oh my God, you have to taste this." It's a great place to chill with friends to catch up, check in and wind down.

The Wine Vault \& Bistro is open from 6 to 11 p.m., and sometimes a little later, on Thursdays and Fridays, but check the online calendar before you go because days and hours can vary. On Saturdays the bistro offers special food-and-wine-pairing dinners that run $\$ 45$ - see their website for more information. Wines by the glass are $\$ 6$ and up, and wine flights range from $\$ 12$ to $\$ 16$. Bistro menu dishes run from $\$ 2$ to $\$ 12$. 


\section{EXHIBIT 2: SAMPLE SATURDAY NIGHT CHEF'S 5-COURSE TASTING MENU}

Saturday | 13 June 2009

\section{CHEF'S 5-COURSE TASTING MENU - 30}

house smoked salmon | new potato salad | sauce gribiche | micro greens chino farms corn soup | guanciale | micro cilantro peach + bourbon glazed pork belly | pickled peaches | fried green tomato lamb osso buco | eggplant fondue | tomato confit | summer beans shortbread | strawberry ice cream | lavender honey | mascarpone

OYSTERS ON THE $1 / 2$ SHELL - 7 four hood canal (british columbia) oysters

cocktail sauce | horseradish granite | pepper mignonette

CHEESE PLATTER - 15

four artisan cheeses (chef's choice)

housemade lavosh | accompanying accoutrements

\section{CHOCOLATE TRUFFLES - 8}

five artisan truffles: passion fruit caramel | rose water caramel sea salt | tarragon orange | guava passion fruit

WINE PAIRING - 20 (add 12 for champagne split) nv piper-heidsieck brut champagne ( $187 \mathrm{ml} 1 / 4$ bottle split) 2007 novy viognier (3 oz. pour) 2007 atrea "the choir" rhone white blend ( 3 oz. pour) 2006 cass grenache ( 3 oz. pour) 2006 reynolds family "stags leap" merlot ( 3 oz. pour) 2004 chateau grand piquey sauternes ( 3 oz. pour)

WINES BY THE GLASS ( 5 oz. pour) nv piper-heidsieck brut champagne $(187 \mathrm{ml} 1 / 4$ bottle split $=6$ oz. $)-12$ 2007 novy viognier -8

2007 atrea "the choir" rhone white blend - 7 2006 cass grenache -8

2006 reynolds family "stags leap" merlot - 12 2004 chateau grand piquey sauternes ( $3 \mathrm{oz}$. pour) -7

\section{WINES BY THE BOTTLE TO DRINK HERE} corkage: wines purchases here - 10 | outside bottles brought in - 20 


\title{
EXHIBIT 3: SAMPLE FRIDAY PRIX FIXE MENU + WINE FLIGHTS
}

\author{
STARTERS \\ blistered shishito peppers $\mid$ sea salt -6 \\ pommes frites | roasted garlic + chipotle aioli dipping sauces - 6 \\ cheese sampler platter $\mathrm{w} /$ four artisan cheeses + accompaniments -15 \\ oysters on the $1 / 2$ shell (1/3 doz.) | cocktail sauce | horseradish granite | pepper mignonette - 8 \\ bacon-wrapped dates stuffed with point reyes blue cheese + almonds -6 \\ black truffle studded mac ' $n$ ' cheese - 7
}

PRIX FIXE 3-COURSE DINNER - 20

pick one from each category below | no sharing please

soups / salads / apps

wild mushroom risotto $\mid$ truffle froth $\mid$ poached farm egg

black mission figs | purple haze chevre goat cheese | 25-year-old balsamic | micro arugula

seared husdon valley foie gras | wild ramp + buttermilk biscuit | lavender honey - $\$ 5$ supplement

tempura fried soft-shell crab | heirloom tomato gazpacho salmorejo - $\$ 3$ supplement

main

duck confit | stewed cherries | frisee | baby fennel

osso buco | polenta | swiss chard | pinenut gremolata

grilled ny strip loin | roasted asparagus | smoked potato purée | truffle jus

rice flake crusted yellowtail $\mid$ arroz a la plancha $\mid$ baby squash $\mid$ basil froth

risotto | sweet peas | pecorino | pea tendrils

sweet

two assorted artisan chocolate truffles

tierra miguel farms organic strawberry mille fleur $\mid$ crème chantilly

34-year-old px sherry sundae | butterscotch ice cream

peach crisp | vanilla bean ice cream

THIS FRIDAY'S PAIRED WINE FLIGHT \$16

The flight ticket includes your choice of four wines: an aperitif wine before dinner plus a wine to pair with all three courses. Each flight is the equivalent of about two-and-a half glasses of wine per person, or the equivalent of approximately a half-bottle of wine.

NV Tobin James "Dreamweaver" Sparkler

2008 Cassagnoles Cótes de Gascogne

2007 Gran Sasso Primitivo

2007 Brewer-Clifton Pinot Noir $(+\$ 3)$

2007 St.-Urbans-Hof Riesling QbA

2004 Chateau Grand Piquey Sauternes

2008 Cass Roussanne

2007 Palmina Dolcetto

2006 Felsina Chianti Classico Berardenga

2004 Cimicky "Reserve" Shiraz (+\$3)

2007 Martin Alfaro "Sleepy Hollow" Chardonnay

2006 Leal "Threesome" Rhone Blend

Chris' Famous "Irish Coffee without the Coffee"

2004 Chateau Grand Piquey Sauternes

Cuarenta y Tres "Licor 43" Spanish Liqueur

Prunier "La Lieutenance" Orange Cognac 
EXHIBIT 4: SAMPLE WINEMAKER DINNER MENU

\section{Brewer Clifton \& Palmina Wine Dinner

\author{
Wine Vault \& Bistro | Wednesday | 29 April 2009
}

\section{Roasted Diver Scallop | Greek Yogurt | Citrus \\ 2007 Palmina "Honea Vineyard" Arneis \$17}

(Santa Ynez Valley) Winemaker's Notes: Aromatic bouquet of honeysuckle and violets laced with a hint of lavender and talc. This feminine nose is delicate in a forthright way and is unleashed from an inviting pale gold hue in the glass. Lilting acidity and freshness wakens the palate and envelopes the taste buds with harmonic layers of kefir lime, wild fennel and then red Anjou pear, Fuji apple and the characteristic marzipan, almond and wild herb finish. Full bodied and ageable, as one might expect from this individualist grape, Arneis will pair beautifully with savory dishes, seafood and hearty fare. We recommend serving just slightly chilled to fully enjoy both the sensory essence of the wine. ( $5 \mathrm{oz}$. pour)

\section{Shrimp-Stuffed Zucchini Blossom Toasted Somen Noodles | Green Garlic 2007 Brewer-Clifton "Santa Rita" Chardonnay \$37}

(Santa Rita Hills) Winemaker's Notes: A combination of four select and diverse vineyard sites along the Highway 246 corridor in the heart of the appellation. Aromas of lemon curd, lime, quince and flint followed by flavors of lemon drop, sage and bee pollen. Brisk, crystalline and driven in the mouth. 14,400 bottles produced. ( 3 oz. pour)

\section{Crispy Sweetbreads | Morel Mushrooms + Black Truffles | Fava Beans 2007 Palmina Dolcetto \$17}

(Santa Barbara County) Winemaker's Notes: Dark ruby color with amethyst highlights. Nose of raspberry and cherry, a bit of toast and a hint of violets. At a first taste, the smooth texture caresses the palate with summertime notes of black cherry, fresh red plums, and wild berries like blackberry, huckleberry and dark raspberries. Yet with all the intense fruit flavors, there's a nice underlying bright acid in the wine and soft, almond-like tannins on the finish. Ready to drink now. Ideally serve with an ever-soslight chill. (3 oz. pour)

\section{Lardo Wrapped Kurobota Pork Loin | Fregula | Wild Ramps 2007 Brewer-Clifton "Santa Rita" Pinot Noir \$37}

(Santa Rita Hills) Winemaker's Notes: Three significant and select vineyard sites from diverse pockets within the appellation comprise this inaugural release. Aromas of black raspberry, dried rose petal and lavender followed by flavors of pomegranate, black cherry and dried orange peel. Firm, chalky and lingering mouthfeel. 12,960 bottles produced. (3 oz. pour)

\section{Pappardelle Pasta | Braised Lamb Shoulder | Horseradish 2006 Palmina "Alisos" Sangiovese/Merlot Blend \$25}

(Santa Barbara County) Winemaker's Notes: $80 \%$ Sangiovese, $16 \%$ Merlot $+4 \%$ Apassiemento Sangiovese. Initial aromatics of pomegranates, pecans, and cherry cola are followed by wafts of dried plum, red currant and herbal notes of bay leaf and laurel. A sip confirms the nose, but is additionally rewarded by a smooth and silky texture as Alisos glides across the palate, leaving remembrances of dried raspberry and cherry from the Sangiovese, earthy and meaty dark notes from the Merlot and herbs d'provencal nuances from the Apassiemento Sangiovese. The lively acidity, barrel aged tannins and layered structure allow the soft fruits to show through in this superbly balanced wine. (3 oz. pour)

\section{Osso Buco | Polenta | Swiss Chard | Pinenut Gremolata 2005 Palmina "Undici" Sangiovese \$33}

(Santa Ynez Valley) Winemaker's Notes: The 2005 Undici has a scarlet, cinnabar hue alight with ruby accents. A spicy nose of violet, plum, rose petal and cedar with a hint of menthol is unleashed by a swirl of the glass. The first sip foretells of layers of flavors, elegantly interlaced with bright acids and dusty baker's cocoa tannins. Dried blueberry and raspberry notes mingle with red plums, currant and clove. Beautifully balanced with a firm, elegant texture and lingering finish replete with wild herbs and bittersweet mocha. ( $3 \mathrm{oz}$. pour)

\section{Dessert?}

Artisan Chocolate Truffles | Dessert Wines | Cognac | Mocha Espresso Martinis Chocolate truffles (\$8 for five), port and dessert wines (\$5-7) and cognac and martinis (\$10) are also available. Ask your server! 


\section{Reynolds Family Flight Ticket $\sim \$ 15$}

2006 Reynolds Family Chardonnay

(Napa Valley) Winemaker's Notes: Creamy caramel to start with a touch of ripe pear. Well balanced tropical fruits and a slight touch of tangerine that finishes with smooth caramel and mouth watering citrus. A refreshing, food-friendly nonmalolactic style of Chardonnay. 1,100 cases produced.

NOTES:

Get another glass to drink here (5 oz. pour) .......................\$10

Get a bottle to take home.

$\sim \sim \sim \sim \sim \sim \sim \sim \sim \sim \sim \sim \sim \sim \sim \sim$

2006 Reynolds "Carneros" Pinot Noir (Carneros) Winemaker's Notes: Ripe raspberries with a hint of vanilla bean followed by candied cherries with a touch of pomegranate on the tip of the palate. 650 cases produced. NOTES:

Get another glass to drink here (5 oz. pour) .....................\$13

Get a bottle to take home.

\section{Reynolds "Stags Leap" Merlot}

(Stags Leap District) Winemaker's Notes: An elegant Merlot with a nose of plum, blueberries, dark cherries and juicy blackberries surrounded by crushed violets, plums and a hint of rosemary. 600 cases produced.

NOTES:

Get another glass to drink here (5 oz. pour) .......................\$12

Get a bottle to take home

\section{Reynolds "Persistence" Red Wine}

(Napa Valley) Winemaker's Notes: 60\% Cabernet Sauvignon, $15 \%$ Merlot, 15\% Cabernet Franc, $8 \%$ Syrah $+2 \%$ Petite Verdot. Ripe raspberry along with soft tannins and big jammy flavors followed with blueberries and dark plum. Extremely food friendly. 1,585 cases produced.

NOTES:

Get another glass to drink here (5 oz. pour) ..................... \$14

Get a bottle to take home...

\section{Wine Vault \& Bistro www.WineVaultBistro.com 619.295.3939}

